\title{
High-flow cannulas will be required with current COVID-19 crisis, not only mechanical ventilators
}

\section{La crisis por COVID-19 hará necesaria cánulas de alto flujo, además de ventiladores mecánicos}

\author{
Edgar Santos, ${ }^{1 *}$ Francisco L. Ramírez-Cuapio, ${ }^{1}$ Lorena T. Remes-Díaz ${ }^{2}$ and \\ Renán Sánchez-Porras ${ }^{1}$ \\ ${ }^{1}$ University of Heidelberg, Department of Neurosurgery, Heidelberg, Germany; ${ }^{2}$ nstituto Mexicano del Seguro Social, Regional General Hospital \\ 46, Guadalajara, Jalisco, Mexico
}

COVID-19 is characterized by acute respiratory distress syndrome progression, ${ }^{1}$ which ranges from mild to severe. ${ }^{2} \mathrm{~A}$ percentage of critically ill patients will require endotracheal intubation and mechanical ventilation; therefore, Mexican engineers from different places have had the initiative of creating mechanical ventilators. ${ }^{3-5}$

Although artificial ventilator is one of the last resources for the most severely ill patients, there are patients who are on the verge of not meeting the criteria for intubation; if they are directly intubated, the opportunity for them to overcome the severe phase with high concentration supplemental oxygen would be be missed. Intubation per se induces lung damage, increases the risk of superinfection, and the number of days of ICU stay. ${ }^{6,7}$ Furthermore, non-selective use of artificial ventilators decreases the opportunity for patients who require a ventilator to survive and increases institutional care costs of both human and material resources.

High-flow oxygen cannulas function is to provide high concentrations of oxygen to the patient, which are not reached with normal nasal prongs or masks. ${ }^{8-10}$ At some point, supplemental oxygen with nasal prongs is not tolerated by the patient and produces dryness, loss of heat in the airway, bleeding, nasal mucosa lesions and pain. High-flow oxygen cannulas are much simpler than an artificial ventilator, since their only function is to mix oxygen with warm water to humidify, bring the gas mixture to body temperature and decrease the discomfort of having oxygen at high concentrations in the airways (Fig. 1). In addition to the benefit of not requiring sedation, they reduce stress, improve breathing and promote deep breaths, thus increasing alveolar ventilation. Additionally, the patient requires less nursing care, he/she can even eat, drink and sleep under normal conditions. Owing to the nature of the patients with COVID-19, whose main problem is hypoxia, high-flow nasal cannula oxygenation appears more convenient than non-invasive intermittent ventilation, since respiratory needs can exceed $50 \mathrm{~L} /$ hour and a normal mask can only provide approximately 10 L/hour of oxygen, in addition to mixing air with oxygen; with high-flow cannulas, up to 50 liters of oxygen can be provided, without the need to dilute with air. ${ }^{8}$

In addition to the above advantages, it is important to make two observations:

- The use of high-flow oxygen cannulas can produce aerosol, and the procedure should therefore be carried out in rooms with negative pressure. When implementing negative pressure is not possible, devices can be used to isolate patient aerosols, for example, covers of different materials, helmets, etc.

- This material resource is not available in the secondary care public institutions that have been designated as COVID reconversion centers, and those existing in tertiary care hospitals will probably be insufficient. 


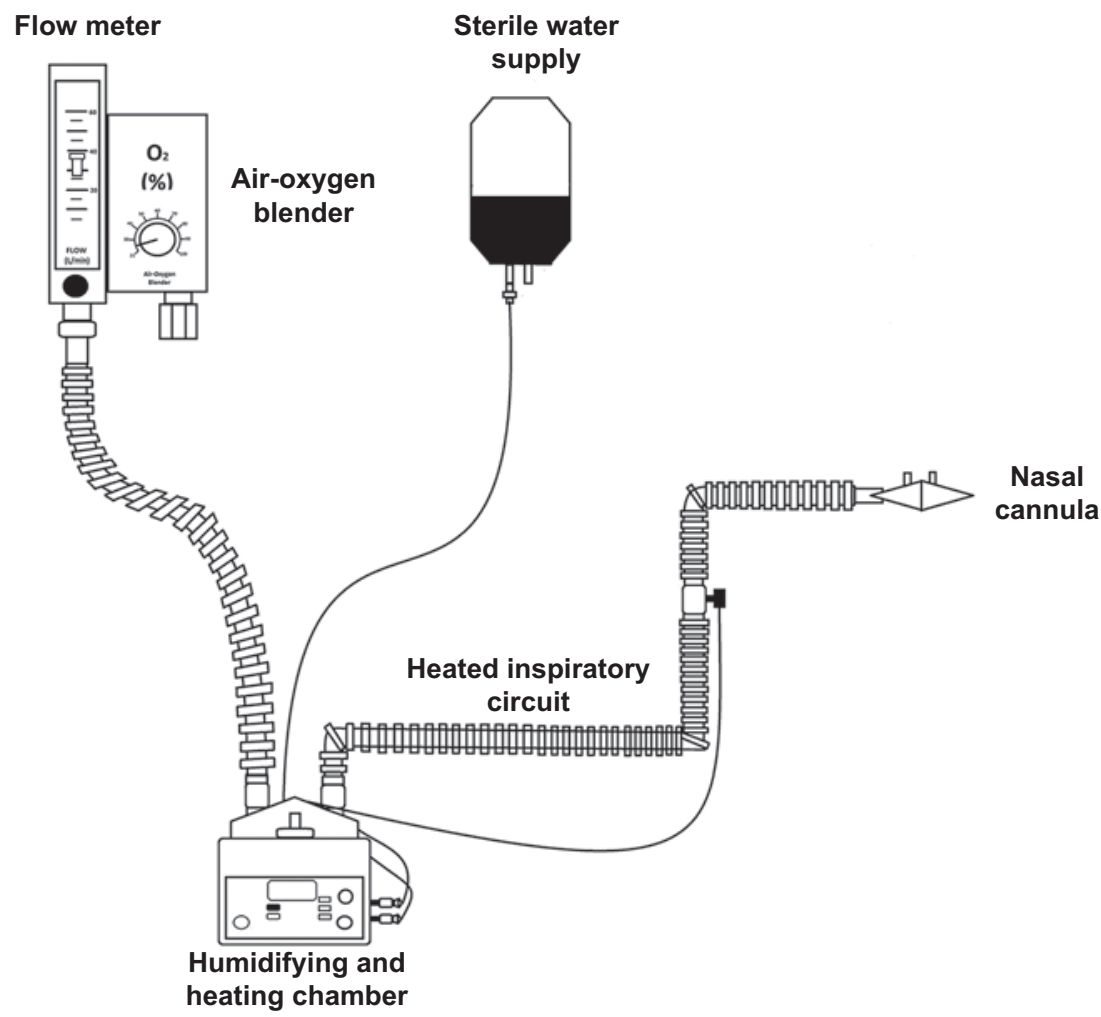

Figure 1. General diagram of a high-flow cannula.

The high-flow oxygen system would reduce the need for intubation in acute patients $\mathrm{s}^{11,12}$ and has the potential to save lives due to the easiness of its use in clinical practice, the reduction of costs, the limitation of biological risk for the medical team during the protection of the airway and the release of ventilators for other patients who do require them. In addition, it can decrease intensive care unit days of stay, which will be especially important when ventilators and beds in intensive care units become scarce or unavailable due to the number of patients.

We suggest to the government authorities to urgently purchase these devices, and to the engineers, companies and research centers, to also focus on the production of high-flow cannulas.

\section{Conflict of interests}

The authors have no conflicts of interest.

\section{Funding}

The authors did not receive any sponsoring to carry out this manuscript.

\section{References}

1. Palacios-Cruz M, Santos E, Velázquez-Cervantes MA, León-Juárez M. COVID-19, una emergencia de salud pública mundial. Rev Clin Esp. 2020. [Epub ahead of print]

2. Huang C, Wang Y, Li X, Ren L, Zhao J, Hu Y, et al. Clinical features of patients infected with 2019 novel coronavirus in Wuhan, China. Lancet. 2020;395:497-506.

3. Cano LC. Ingenieros crean respirador artificial básico de bajo precio. El Diario [online] April 03.

4. Roa P. Ingenieros mexicanos crean respiradores sin fines de lucro para pacientes con coronavirus. Infobae [online] March 31.

5. Barrera KH. Profesor de la Universidad de Sonora crea respirador artificial de bajo costo. SDPnoticias [online] March 31.

6. Girou E, Schortgen F, Delclaux C, Brun-Buisson C, Blot F, Lefort Y, et al. Association of noninvasive ventilation with nosocomial infections and survival in critically ill patients. JAMA. 2000;284:2361-2367.

7. Girou E, Brun-Buisson C, Taillé S, Lemaire F, Brochard L. Secular trends in nosocomial infections and mortality associated with noninvasive ventilation in patients with exacerbation of COPD and pulmonary edema. JAMA. 2003;290:2985-2991.

8. Roca O, Riera J, Torres F, Masclans JR. High-flow oxygen therapy in acute respiratory failure. Respir Care. 2010;55:408-413.

9. Lenglet $H$, Sztrymf B, Leroy C, Brun P, Dreyfuss D, Ricard JD. Humidified high flow nasal oxygen during respiratory failure in the emergency department: feasibility and efficacy. Respir Care. 2012;57:1873-1878.

10. Stéphan F, Barrucand B, Petit $P$, Rézaiguia-Delclaux S, Médard A, Delannoy $B$, et al. High-flow nasal oxygen vs noninvasive positive airway pressure in hypoxemic patients after cardiothoracic surgery: a randomized clinical trial. JAMA. 2015;313:2331-2339.

11. Frat JP, Thille AW, Mercat A, Girault C, Ragot S, Perbet S, et al. High-flow oxygen through nasal cannula in acute hypoxemic respiratory failure. N Engl J Med. 2015;372:2185-2196.

12. Alhazzani W, Møller MH, Arabi YM, Loeb M, Gong MN, Fan E, et al. Surviving sepsis campaign: guidelines on the management of critically ill adults with coronavirus disease 2019 (COVID-19). Intensive Care Med. 2020:1-34. 